$$
\begin{array}{ll}
\text { Volume } & : 05 \\
\text { Nomor } & : 03 \\
\text { Bulan } & : \text { September } \\
\text { Tahun } & : 2019 \\
\text { http } & : / / \text { ejurnal.pps.ung.ac.id/index.php/AKSARA/index }
\end{array}
$$

\title{
MENINGKATKAN KOMPETENSI PEDAGOGIK GURU MELALUI PELATIHAN BERJENJANG
}

\author{
Trisnawaty B. Utiarahman \\ SMP NEGERI 4 MARISA \\ Email: trisnawatyutiarahman@gmail.com
}

Received: 02 Juni 2019; Revised: 19 Juli 2019; Accepted: 25 Agustus 2019

\begin{abstract}
ABSTRAK
Rendahnya profesionalisme terutama kompetensi pedagogik guru di SMP Negeri 1 Marisa merupakan masalah yang sangat mendesak untuk ditangani melalui penerapan pelatihan berjenjang model-model pembelajaran inovatif. Metode yang digunakan dalam penelitian ini adalah desain penelitian tindakan sekolah melalui 2 (dua) siklus, yang masingmasing melalui tahap perencanaan, implementasi, observasi, dan refleksi. Objek penelitian adalah guru mata pelajaran tahun pelajaran 2016/2017 yang berjumlah 6 orang, terdiri dari 2 orang guru mata pelajaran IPA (Biologi dan Fisika) dan 2 orang guru mata pelajaran Bahasa Indonesia, 1 orang guru mata pelajaran matematika dan 1 orang guru mata pelajaran Bahasa Inggris. Hasil akhir dari penelitian ini menunjukkan bahwa dengan penerapan pelatihan/workshop berjenjang dapat meningkatkan kompetensi pedagogik dan penguasaan konsep kompetensi pedagogik guru di SMP Negeri 4 Marisa. Disamping itu penerapan pelatihan berjenjang sangat menentukan, kesiapan instruktur dan guru dalam mengikuti pelatihan serta dukungan dan motivasi dari kepala sekolah.
\end{abstract}

Kata Kunci: Kompetensi Pedagogik, Pelatihan Berjenjang.

\section{PENDAHULUAN}

Kegiatan pembelajaran selama ini cenderung berjalan dengan menempatkan guru sebagai pusat informasi, pusat segala aktivitas, bahkan sering sebagai satu-satunya sumber informasi dan berperan dominan dalam kelas. Guru mendesain dan melaksanakan kegiatan pembelajaran sedemikian rupa, sehingga terkesan kaku, sunyi, menoton, terlalu serius, tanpa kegembiraan, sehingga membosankan bagi siswa (Anonim, 2006).

Suasana pembelajaran yang dilaksanakan guru di sekolah selama ini membuat siswa menjadi pasif, tidak kreatif, bahkan menimbulkan kebosanan, karena konsep-konsep yang disampaikan sulit dipahami. Akibatnya, cara yang ditempuh siswa dalam upaya memahami suatu konsep adalah dengan cara sekedar menghafal tanpa berpikir tentang bagaimana kebenaran konsep itu dan apa manfaat konsep itu dipelajari.

Kompetensi guru-guru di SMP Negeri 4 Marisa yang didominasi oleh guru-guru muda belum menunjukkan profesionalisme yang mamadai sesuai tuntutan Permendiknas No. 16 Tahun 2007 yaitu seorang guru yang profesional. Guru Profesional apabila memiliki kompetensi pedagogik, kepribadian, sosial, dan profesional. Khusus kompetensi pedagogik masih sangat perlu ditingkatkan, terutama yang berhubungan dengan penyajian pembelajaran di kelas, penguasaan teori-teori belajar, dan penilaian. Secara umum guru di SMP Negeri 4 Marisa belum memiliki kompetensi pedagogik berkategori baik. Kemampuan yang dianggap kurang dari kompetensi pedagogik tersebuat adalah kemampuan berinovasi dalam merancang dan melaksanakan pembelajaran dengan menggunakan model-model pembelajaran. Kondisi ini masih jauh dari harapan sebagai salah satu sekolah potensial di Kabupaten Pohuwato. 


$\begin{array}{ll}\text { Volume } & : 05 \\ \text { Nomor } & : 03 \\ \text { Bulan } & : \text { September } \\ \text { Tahun } & : 2019 \\ \text { http } & : / / \text { ejurnal.pps.ung.ac.id/index.php/AKSARA/index }\end{array}$

Menurut (Slavin, 1986), jika seseorang diberi pelatihan dan bimbingan secara berjenjang, maka lambat laun akan terjadi peubahan tingkah laku. Perubahan tingkah laku ke arah positif jika mereka memperoleh makna dari pelatihan tersebut. Pengalaman yang bermakna dapat diciptakan melalui pembentukan stimulus berupa pemberian reword dan pembinaan secara tulus dan berkesinambungan serta menghindari adanya hukuman.

Dipilihnya pendekatan pelatihan/workshop model-model pembelajaran inovatif dalam meningkatkan kompetensi pedagogik guru di SMP Negeri 4 Marisa karena sebagian besar guru di SMP Negeri 4 Marisa tersebut belum memahami tentang teori-teori belajar dan model-model pembelajaran inovatif. Pendekatan pelatihan akan memberi dampak ganda berupa perolehan pengetahuan dan finansial bagi guru, sehingga guru akan termotivasi dalam mengikuti kegiatan tersebut guna meningkatkan kompetensi pedagogik dalam melaksnakan tugasnya di sekolah.

\section{KAJIAN PUSTAKA \\ Peranan Kepemimpinan Kepala Sekolah dalam Peningkatan Kompetensi Guru}

Dalam pencaian tujuan sekolah sangat ditentukan sosok pimpinan yang visioner, dan mempunyai keribadian yang kuat. Menurut Wahab (2008: 132) kepemimpinan adalah proses mempengaruhi kegiatan-kegiatan kelompok yang diorganisir menuju kepada penentuan dan pencapaian tujuan. Dari defenisi tersebut dapat diambil kesimpulan bahwa kepemimpinan adalah suatu kualitas kegiatan-kegiatan kerja dan interaksi di dalam situasi kelompok. Dari kenyataan tersebut dapat dikatakan bahwa kepemimpinan pendidikan adalah suatu kualitas kegiatan-kegiatan dan integrasi di dalam situasi pendidikan. Kepemimpinan pendidikan merupakan kemampuan untuk menggerakan pelaksana pendidikan, sehingga tujuan pendidikan yang telah ditetapkan dapat tercapai secara efisien dan efektif.

Kepemimpinan pendidikan yang efektif dapat meningkatkan partisipasi warga sekolah dan masyarakat. Menurut Syafiuddin dan Fatimah (2007) mengatakan bahwa peningkatan partisipasi warga sekolah dan masyarakat dalam penyelenggaraan sekolah akan mampu menciptakan: (1) keterbukaan (transparansi); (2) kerja sama yang kuat; (3) akuntabilitas; dan (4) demokrasi pendidikan. Transparansi (keterbukaan) yang dimaksud adalah keterbukaan dalam program dan keuangan. Kerja sama yang dimaksud adalah adanya sikap dan perbuatan lahiriah kebersamaan untuk meningkatkan mutu sekolah. Kerja sama yang baik ditunjukkan oleh hubungan antarwarga sekolah yang erat, hubungan sekolah dan masyarakat yang erat, dan adanya kesadaran bersama bahwa output sekolah merupakan hasil kolektif teamwork yang kuat dan cerdas. Artinya, prestasi yang diraih ataupun mutu yang dicapai merupakan jerih payah upaya kolektif antara kepala sekolah, seluruh staf, dan dibantu oleh orang tua dan masyarakat dalam wadah Komite Sekolah. Oleh karena itu, kepemimpinan pendidikan yang diterapkan di sekolah adalah kepemimpinan partisipatif, kolaboratif, dan demokratis. Dengan kepemimpinan partisipatif, akan tumbuh komitmen bersama untuk meningkatkan mutu pendidikan sebagai realisasi program yang dibuat/disusun dengan melibatkan warga sekolah dan wakil orang tua dan masyarakat.

\section{Pengertian Kompetensi Guru}

Kompetensi guru menurut Fachruddin dan Ali (2009: 30), adalah suatu hal yang menggambarkan kualifikasi atau kemampuan seseorang, baik yang kialitatif maupun yang kuantitatif. Kemampuan kualitatif seseorang adalah kemampuan sikap dan perbuatan seseorang yang hanya dapat dinilai dengan ukuran baik dan buruk. Sedangkan kuantitatif adalah kemampuan seseorang yang dapat dinilai dengan ukuran. Berdasarkan pengertian ini, berarti kompetensi guru mengandung makna sebagai indicator kemampuan yang 


$\begin{array}{ll}\text { Volume } & : 05 \\ \text { Nomor } & : 03 \\ \text { Bulan } & : \text { September } \\ \text { Tahun } & : 2019 \\ \text { http } & : / / \text { ejurnal.pps.ung.ac.id/index.php/AKSARA/index }\end{array}$

menunjukkankepada perbuatan yang dapat diamati, yakni seperangkat teori ilmu pengetahuan dalam bidangnya. Juga kompetensi sebagai konsep yang mencakup aspek-aspek kognitif, afektif, dan perbuatan serta tahapan-tahapannya secara utuh.

Sementara Mulyasa, E. (2005: 20), mengatakan bahwa kompetensi adalah penguasan terhadap tugas, keterampilan, sikap, dan apresiasi yang diperlukan untuk menunjang keberhasilan. Dilain pihak Depdiknas (2007) mengartikan kompetensi sebagai pengetahuan, keterampilan dan nilai-nilai dasar yang direfleksikan dalam kebiasan berpikir dan bertindak. Sementara kompetensi menurut Kepmendiknas 045/U/2002 adalah; seperangkat tindakan cerdas, penuh tanggungjawab yang dimiliki seseorang sebagai syarat untuk dianggap mampu oleh masyarakat dalam melaksanakan tugas-tugas di bidang pekerjaan tertentu. Hal senada diungkapkan dalam PP nomor 19 tahun 2005, tentang Standar Nasional Pendidikan, pada pasal 28, ayat 3 disebutkan bahwa kompetensi guru sebagai agen pembelajaran pada jenjang pendidikan dasar dan menengah serta pendidik pada usia dini meliputi; (1) kompetensi pedagogic, (2) kompetensi professional, (3) kompetensi kepribadian, dan (4) kompetensi social.

Dari beberapa pengertian kompetensi seperti tersebut di atas maka yang dimaksud dengan kompetensi guru dalam penelitian ini adalah sejumlah kemampuan yang harus dimiliki guru untuk mencapai tingkatan guru professional. Kompetensi guru meliputi kompetensi pedagogik, kompetensi professional, kompetensi kepribadian, dan kompetensi sosial.

Selain itu guru yang professional juga dituntut memiliki kode etik, yaitu norma tertentu sebagai pegangan yang diakui serta dihargai oleh masayarakat. Kode etik ini merupakan cerminan dari kompetensi yang harus dimiliki oleg seorang guru sesuai yang tertuang dalam Permendiknas nomor 16 tahun 2007 tentang guru. Menurut Tilaar dalam Buchari Alma (2009:132) guru yang professional dituntut untuk memiliki lima hal, yaitu: (1) guru mempunyai komitmen pada siswa dan proses belajar mengajar, (2) guru menguasai secara mendalam mata pelajaran yang diajarkannya, (3) guru bertanggungjawab memantau hasil belajar melalui berbagai cara evaluasi, (4) guru mampu berpikir sistematis, dan (5) guru seyogyanya merupakan bagian dari masyarakat belajar dan lingkungan profesinya.

Keempat kompetensi tersebut terintegrasi dalam kinerja guru. Standar kompetensi guru mencakup kompetensi inti guru yang dikembangkan menjadi kompetensi guru PAUD/TK/RA, guru kelas SD/MI, dan guru mata pelajaran pada SD/MI, SMP/MTs, SMA/MA, dan SMK/MAK. Standar-standar tersebut dirinci lebih khusus menjadi 10 kemampuan dasar guru, yaitu; (1) penguasaan bahan pelajaran beserta konsep-konsep dasar keilmuannya, (2) pengelolaan program belajar mengajar, (3) pengelolaan kelas, (4) penggunaan media dan sumber balajar, (5) penguasaan landasan-landasan pendidikan, (6) pengelolaan interaksi belajar mengajar, (7) penilaian prestasi siswa, (8) pengenalan fungsi dan program bimbingan dan penyuluhan, (9) pengenalan dan penyelenggaraan administrasi sekolah, dan (10) pemahaman prinsip-prinsip dan pemanfaatan hasil penelitian pendidikan untuk kepentingan peningkatan mutu pengajaran, (Buchari Alma, 2009: 139). Berdasarkan standar seorang guru yang professional, guru hendaknya memiliki kemampuan atau kompetensi yaitu seperangkat kemampuan sehingga dapat mewujudkan kinerja profesionalnya.

\section{Jenis-jenis Kompetensi Guru \\ Kompetensi Pedagogik}

Pedagogik diartikan sebagai ilmu pendidikan yang lebih menekankan pada pemikiran dan perenungan tentang pendidikan. Menurut Fahruddin dan Ali (2009: 32) pedagogik diartikan sebagai pendidikan yang lebih menekankan kepada praktek, yang menyangkut kegiatan 


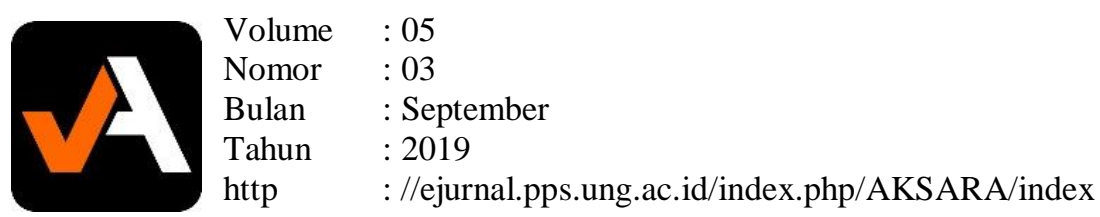

mendidik dan membimbing peserta didik. Berdasarkan pengertian tersebut, amak yang dimaksud dengan pedagogic adalah ilmu tentang pendidikan anak yang ruang lingkupnya terbatas pada interaksi edukasi antara pendidik dengan peserta didik. Sedangkan kompetensi pedagogik adalah sejumlah kemampuan guru yang berkaitan dengan ilmu dan seni mengajar siswa.

Ruang lingkup dari kompetensi pedagogik yang dirumuskan dalam PP nomor 19 tahun 2005 tentang Standar Nasional Pendidikan, pasal 28, ayat 3, menyebutkan bahwa kompetensi pedagogic ialah kemampuan mengelola pembelajaran peserta didik yang meliputi (1) pemahaman peserta didik, (2) perancangan dan pelaksanaan pembelajaran, (3) evaluasi hasil belajar, (4) pengembangan peserta didik untuk mengaktualisasikan berbagai potensi yang dimilikinya. Sementara Muchlas Samani, (2008: 6) kompetensi pedagogic adalah kemampuan dalam pengelolaan pembelajaran peserta didik yang meliputi; (1) pemahaman wawasan, (2) pemahaman peserta didik, (3) pengembangan kurikulum/silabus, (4) perancangan pembelajaran, (5) pemanfaatan teknologi pembelajaran, (6) evaluasi proses dan hasil belajar, dan (7) pengembangan peserta didik untuk mengaktualisasikan berbagai potensi yang dimikinya.

Kompetensi pedagogik. Mencakup konsep kesiapan mengajar yang ditujukan pada penguasaan pengetahuan dan keterampilan mengajar. Menurut Depdiknas (2007) kompetensi pedagogik untuk guru mata pelajaran meliputi beberapa kompetensi inti meliputi: (1) Menguasai karakteristik peserta didik dari aspek fisik, moral, spiritual, sosial, kultural, emosional, dan intelektual, (2) Menguasai teori belajar dan prinsip-prinsip pembelajaran yang mendidik, (3) Mengembangkan kurikulum yang terkait dengan mata pelajaran yang diampu, (4) Menyelenggarakan pembelajaran yang mendidik, (5) Memanfaatkan teknologi informasi dan komunikasi untuk kepentingan pembelajaran, (6) Memfasilitasi pengembangan potensi peserta didik untuk mengaktualisasikan berbagai potensi yang dimiliki, (7) Berkomunikasi secara efektif, empatik, dan santun dengan peserta didik, (8) Menyelenggarakan penilaian dan evaluasi proses dan hasil belajar, (9) Memanfaatkan hasil penilaian dan evaluasi untuk kepentingan pembelajaran, dan (10) Melakukan tindakan reflektif untuk peningkatan kualitas pembelajaran. Berdasarkan kompetensi inti yang harus dimiliki oleh seorang guru, maka tugas mengajar merupakan pekerjaan yang kompleks dan sifatnya multidimensional.

Berdasarkan beberapa pengertian kompetensi pedagogik seperti tersebut di atas, dapatlah dikatakan bahwa guru yang professional mempunyai kemampuan-kemampuan sebagai berikut; menguasai landasan mengajar, menguasai ilmu mengajar, mengenal siswa, menguasai teori motivasi, mengenal lingkungan masyarakat, menguasai penyusunan kurikulum, menguasai teknik penyusunan RPP, dan menguasai pengetahuan evaluasi pembelajaran.

\section{Kompetensi Kepribadian}

Kemampuan professional adalah kemampuan yang stabil, dewasa, arif, berwibawa, menjadi teladan, dan berahlak mulia, (Udin Syaefuddin, 2009: 51). Sejalan dengan pendapat tersebut makan Depdiknas, 2007 menguraikan kompetensi inti dari kompetensi kepribadian seorang guru yaitu: (1) bertindak sesuai dengan norma agama, hukum, sosial,dan kebudayaan nasional Indonesia, (2) menampilkan diri sebagai pribadi yang jujur, berakhlak mulia, dan teladan bagi peserta didik dan masyarakat, (3) menampilkan diri sebagai pribadi yang mantap, stabil, dewasa, arif, dan berwibawa, (4) menunjukkan etos kerja, tanggung jawab yang tinggi, rasa bangga menjadi guru,dan rasa percaya diri, (5) menjunjung tinggi kode etik profesi guru. Sejalan dengan inti dari kompetensi kepribadian terebaut, maka akan berdampak pada guru yang dihormati dan disegani oleh siswanya. Jadi guru harus bertekad 


$\begin{array}{ll}\text { Volume } & : 05 \\ \text { Nomor } & : 03 \\ \text { Bulan } & : \text { September } \\ \text { Tahun } & : 2019 \\ \text { http } & : \text { //ejurnal.pps.ung.ac.id/index.php/AKSARA/index }\end{array}$

mendidik dirinya sendiri lebih dahulu sebelum mendidik orang lain. Pendidikan melalui keteladanan adalah pendidikan yang paling efektif.

Guru yang disegani, otomatis mata pelajaran yang diajarkan akan disenangi oleh siswa, dan siswa akan bergairah dan termotivasi sendiri mendalami mata pelajaran yang diajarkan oleh guru. Sebaliknya guru yang dibenci oleh muridnya, akan tidak senang dengan mata pelajaran yang diajarkan oleh guru, dan membentuk sikap antipasti terhadap mata pelajaran yang dipelajari tersebut.

\section{Kompetensi Sosial}

Kompetensi social adalah kemampuan guru untuk berkomunikasi dan berinteraksi secara efektif dengan lingkungan sekolah dan di luar lingkungan sekolah, (Buchari Alma, 2009: 142). Menurut Depdiknas, 2007 kompetensi social dijabarkan ke dalam beberapa kompetensi inti antara lain: (1) Bersikap inklusif, bertindak objektif, serta tidak diskriminatif karena pertimbangan jenis kelamin, agama, ras, kondisi fisik, latar belakang keluarga, dan status sosial ekonomi, (2) Berkomunikasi secara efektif, empatik, dan santun dengan sesama pendidik, tenaga kependidikan, orang tua, dan masyarakat, (3) Beradaptasi di tempat bertugas di seluruh wilayah Republik Indonesia yang memiliki keragaman social budaya, dan (4) Berkomunikasi dengan komunitas profesi sendiri dan profesi lain secara lisan dan tulisan atau bentuk lain. Oleh karena itu guru professional harus mengembangkan komunikasi dengan orang tua siswa, sehingga terjalin komunikasi dua arah yang berkelanjutan antara sekolah dengan orang tua, serta masyarakat pada umumnya.

Seorang guru juga diharapkan memiliki jiwa enterpreurship, yang berarti seorang yang kreatif, inovatif selalu bisa mencari solusi dari setiap permasalahan, menciptakan sesuatu yang baru, memiliki motivasi tinggi.

\section{Kompetensi Profesional}

Kemampuan professional adalah kemampuan penguasaan materi pelajaran secara luas dan mendalam, serta metode dan teknik mengajar yang sesuai dan dapat dipahami oleh peserta didik, mudah ditangkap, tidak menimbuklan kesulitan dan keraguan. Kompetensi professional terdiri dari beberapa kompetensi inti antara lain: (1) Menguasai materi, struktur, konsep, dan pola pikir keilmuan yang mendukung mata pelajaran yang diampu, (2) Menguasai standar kompetensi dan kompetensi dasar mata pelajaran yang diampu, dan (3) Mengembangkan materi pembelajaran yang diampu secara kreatif, (Depdiknas, 2007).

\section{METODE PENELITIAN}

Tahapan penelitian tindakan ini diawali dengan pra observasi untuk mengetahui kondisi awal dari masalah rendahnya kompetensi guru dalam bidang pedagogik. Hasil observasi diperoleh bahwa hanya 2 orang guru dari 6 orang guru yang memiliki kompetensi pedagogik yang memenuhi standar.. Untuk memecahkan masalah yang timbul maka dilakukan diskusi mendalam dengan pengawas pembina untuk mencarikan solusi dalam menanggulangi masalah tersebut. Hasil diskusi mendalam diperoleh kesepakatan bahwa pemberian pelatihan secara berjenjang kepada guru akan berdampak positif terhadap peningkatan kompetensi guru yang berhubungan dengan tugas mengajar mereka.

Dari hasil diskusi tersebut selanjutnya dilaksanakan beberapa kegiatan berupa penyusunan rencana tindakan, yaitu penyusunan langkah-langkah pelatihan, penyusunan instrumen observasi dan penilaian kinerja guru serta butir soal tes kompetensi pedagogik. Pelaksanaan tindakan dimaksudkan untuk mengimplementasikan hasil pelatihan. Observasi dan evaluasi dilaksanakan untuk mengetahui adanya peningkatan kemampuan atau kompetensi guru dalam pembelajaran. Refleksi dimaksudkan untuk mengetahui kemajuan dan kelemahan dari pelaksanaan tindakan. 
Secara ringkas pelaksanaan tindakan pada setiap siklus dilakukan dengan prosedur: (1) perencanaan (planning), (2) pelaksanaan tindakan (action),

(3) observasi dan evaluasi (observation and evaluation), dan (4) refleksi (reflection). Untuk jelasnya dapat dilihat pada diagram berikut.

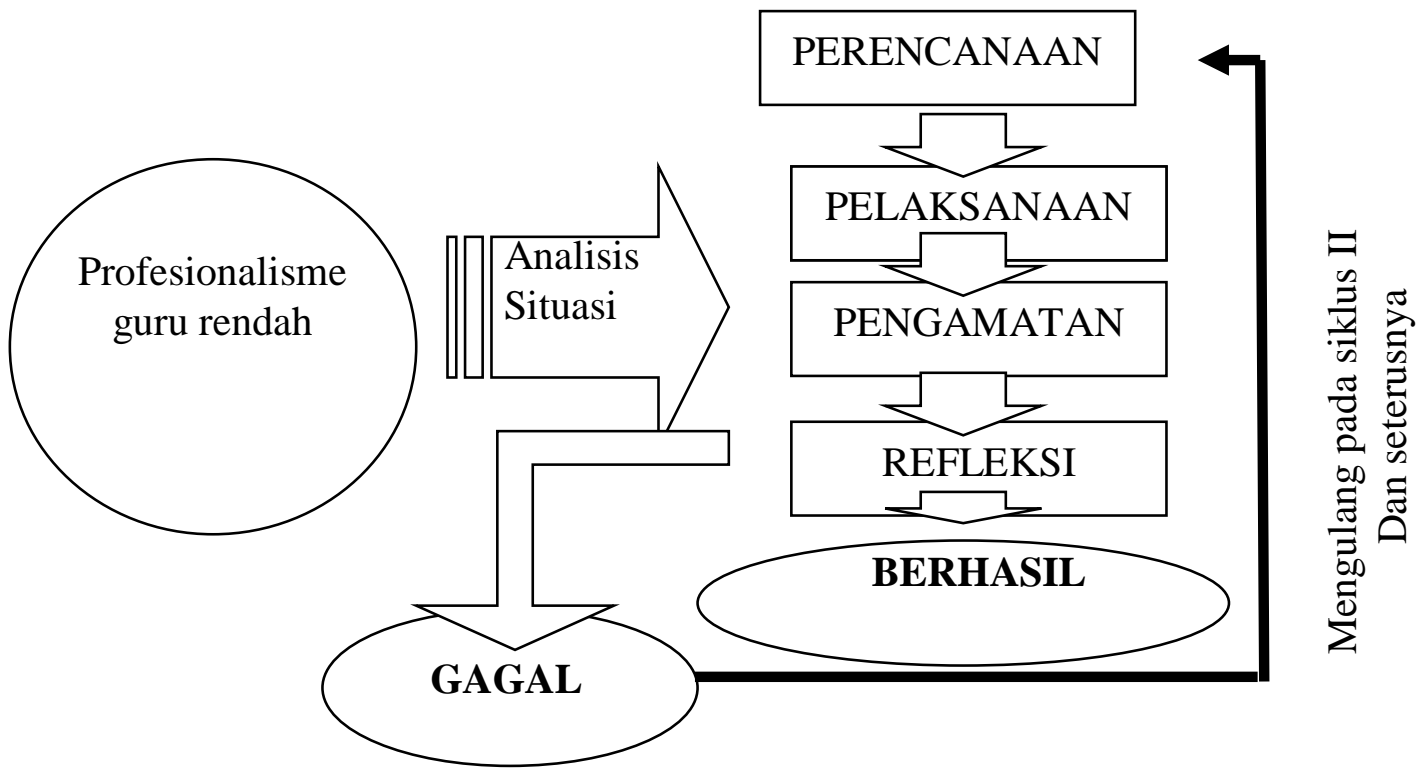

Gambar 1. Siklus rancangan penelitian tindakan (action research)

\section{HASIL PENELITIAN DAN PEMBAHASAN \\ Pelaksanaan Siklus 1 \\ Perencanaan}

Hasil perencanaan penelitian pada siklus 1 diperoleh berupa desain workshop meliputi penguasaan konsep-konsep pembelajaran inovatif, penyusunan model-model pembelajaran, dan implementasi model dalam rencana pelaksanaan pembelajaran.

Instrumen observasi dan evaluasi berupa daftar pengamatan kinerja guru dan efektifitas pelatihan serta tes hasil kompetensi pedagogik guru. Instrumen penilaian hasil kompetensi guru berupa tes bentuk pilihan ganda. Sedangkan lembar observasi kinerja guru dalam pembelajaran mengacu pada beberapa subkompetensi pedagogik seperti yang tertuang dalam Permendiknas nomor 16 tahun 2007 tentang guru. Format ini digunakan saat guru melaksanakan pembelajaran dengan menggunakan model pembelajaran dari hasil pelatihan.

\section{Pelaksanaan Tindakan}

Pelaksanaan tindakan dilaksanakan berdasarkan skenario dan disuaikan dengan rencana pelaksanaan pelatihan/workshop model-model pembelajaran. Pada kegiatan pelatihan disajikan sejumlah materi antara lain, teori-teori belajar, konsep dasar pembelajaran inovatif (PAKEM dan CTL), model-model pembelajaran, dan penyusunan bahan ajar (LKS).

Hasil observasi dari pelaksanaan pelatihan menunjukkan bahwa: (1) guru sangat antusias mengikuti materi pelatihan yang disajikan oleh fasilitator, (2) guru mengatakan memperoleh banyak tambahan pengetahuan yang berhubungan dengan teori-teori belajar dan modelmodel pembelajaran yang inovatif, dan (3) fasilitator atau instruktur sangat menguasai materi pelatihan. Selain keberhasilan yang diperoleh dari pelaksanaan pelatihan maka diperoleh pula 220 


$$
\begin{array}{ll}
\text { Volume } & : 05 \\
\text { Nomor } & : 03 \\
\text { Bulan } & : \text { September } \\
\text { Tahun } & : 2019 \\
\text { http } & : / / \text { ejurnal.pps.ung.ac.id/index.php/AKSARA/index }
\end{array}
$$

beberapa kelemahan pada saat tindakan pelatihan antara lain; (1) terbatasnya waktu yang tersedia karena pelaksanaan pelatihan dilaksanakan pada sore hari usai kegiatan belajar mengajar, (2) kurangnya bahan materi yang disediakan oleh sekolah terutama bahan bacaan yang berhubungan dengan teori-teori belajaran dan materi CTL, dan (3) tidak maksimalnya simulasi model karena hanya diikuti oleh enam (6) orang guru mata pelajaran.

Pada pelaksanaan model pembelajaran hasil pelatihan di kelas diperoleh beberapa keunggulan dari pelatihan antara lain: (1) guru sangat termotivasi dan senang mengajar, (2) pembelajaran di kelas tidak didominasi oleh guru, (3) siswa sangat antusias dalam mengikuti pelajaran, dan (4) pengajaran yang lakukan oleh guru sudah sistematif dan lebih efektif. Selain keunggulan terdapat pula beberapa kelemahan pada pelaksanaan pembelajaran di kelas antara lain: (1) guru masih agak gugup karena diamati oleh kepala sekolah dan pengawas, (2) guru belum memperhatikan karakteristik siswa sehingga model yang diterapkan belum maksimal, dan (3) guru tidak menyediakan sarana penunjang berupa LCD untuk memperjelas konsep yang diajarkan.

\section{Hasil Observasi dan Evaluasi \\ Kinerja Guru}

Penilaian kinerja guru dilaksanakan oleh seorang pengamat kepala sekolah dan pengawas sekolah dengan menggunakan instrumen. Dari hasil pengamatan diperoleh rata-rata skor pada setiap indikator atau sub kompetensi yang diamati. Rata-rata skor kinerja guru pada setiap sub kompetensi dapat disajikan dalam tabel 4.1 berikut, sedangkan data terinci dapat dilihat pada lampiran

Tabel 4.1 Rata-rata Skor Kinerja Kompetensi Pedagogik Guru pada Siklus 1

\begin{tabular}{|l|l|l|}
\hline No. & Sub Kompetensi & $\begin{array}{l}\text { Rata-rata } \\
\text { Skor }\end{array}$ \\
\hline 1. & $\begin{array}{l}\text { Mengenal karakteristik anak didik } \\
\text { 2. }\end{array}$ & $\begin{array}{l}\text { Menguasai teori belajar dan prinsip-prinsip } \\
\text { pembelajaran yang mendidik }\end{array}$ \\
3. & $\begin{array}{l}\text { Pengembangan kurikulum } \\
\text { Kegiatan pembelajaran yang mendidik }\end{array}$ \\
5. & $\begin{array}{l}\text { Memahami dan mengembangkan potensi peserta } \\
\text { didik }\end{array}$ & 3,67 \\
6. & Komunikasi dengan peserta didik & 3,33 \\
7. & Penilaian dan evaluasi & 3,83 \\
& & 3,00 \\
\hline
\end{tabular}

(Sumber : Data Lampiran 5a)

Dari data Tabel 4.1 diperoleh bahwa rata-rata skor kinerja guru pada kompetensi pedagogik yang masih kurang (belum maksimal) adalah subkompetensi mengenal karakteristik peserta didik, menguasai teori-teori belajar dan prinsip-prinsip pembelajaran yang mendidik, memahami dan mengembangkan potensi peserta didik, dan kemampuan guru dalam penilaian dan evaluasi. Setelah dilakukan refleksi, maka penyebab tidak maksimalnya skor yang diperoleh guru dari beberapa subkompetensi pedagogik tersebuat adalah kurangnya literatur pendukung yang dimiliki guru serta belum maksimalnya pelatihan yang diberikan oleh instruktur. Ketidak maksimalan tersebut disebabkan oleh pelaksanaan pelatihan dilaksanakan pada sore hari sehingga para guru merasa kelelahan setelah melaksanakan tugas mengajar di pagi hari. 


$\begin{array}{ll}\text { Volume } & : 05 \\ \text { Nomor } & : 03 \\ \text { Bulan } & : \text { September } \\ \text { Tahun } & : 2019 \\ \text { http } & : / / \text { ejurnal.pps.ung.ac.id/index.php/AKSARA/index }\end{array}$

Berdasarkan beberapa pendapat siswa mengenai kinerja (kompetensi) guru diperoleh kesimpulan bahwa; (1) secara keseluruhan guru belum maksimal seluruh keterampilan mengajar, (2) guru belum melakukan bimbingan secara individual atau kelompok, (3) guru masih mendominasi jalannya pembelajaran, (4) guru kurang mengorganisasikan siswa dan media pembelajaran, dan (5) dalam kegiatan penutup beberapa guru belum membuat rangkuman pembelajaran. Selain itu secara keseluruhan penampilan guru sudah baik walaupun masih sering menggunakan kata-kata yang tidak perlu.

\section{PENUTUP}

Berdasarkan analisis data dan pembahasan hasil penelitian dapat ditarik beberapa kesimpulan sebagai berikut: Penerapan pelatihan/workshop berjenjang dapat meningkatkan kompetensi pedagogik guru di SMP Negeri 4 Marisa. Hasil pelatihan/workshop dapat meningkatkan kinerja guru di SMP Negeri 4 Marisa dalam menerapkan model-model pembelajaran inovatif di kelas.

Penerapan pelatihan/workshop secara berjenjang dapat meningkatkan pemahaman konsep tentang kompetensi pedagogik guru di SMP Negeri 4 Marisa. Kepala sekolah telah mampu meningkatkan kompetensi kepemimpinan pembelajaran dalam pencapaian sekolah yang efektif. Peningkatan kompetensi pedagogik guru ditentukan oleh kemampuan fasilitator dan kesungguhan guru dalam mengikuti kegiatan pelatihan. Peningkatan kompetensi pedagogik guru di SMP Negeri 4 Marisa dapat meningkatkan hasil belajar siswa.

\section{DAFTAR PUSTAKA}

Akhmad Sudrajat. (2008) Manajemen Sekolah dalam Upaya Mengantisipasi Perubahan Online http://akhmadsudrajat.wordpress.com/

Anonim, (2006). Panduan Penyusunan Kurikulum Tingkat Satuan Pendidikan. Jakarta: Pusat Kurikulum Departemen Pendidikan Nasional.

Anonim, (2007). Lampiran Permendiknas Nomor 16 Tahun 2007, tentang Guru.

Aziz Wahab, (2007). Metode dan Model-model Mengajar, Bandung: Alfabeta.

Buchari Alma. (2009). Guru Profesional Menguasai Metode dan Terampil Mengajar. Bandung: Alfabeta.

Chauhan, S. S. (1979) Inovation in Teaching and Learning Process. New Delhi: Vicas Publishing House PVT. LTD.

Dahar, R. W. (1996). Teori-Teori Belajar. Jakarta: Erlangga.

Engge, Paul, dkk. (1979) Strategies for Teachers: Information Processing Models in The Calssroom. New Jersey: Prectise-Hall. Inc. Englewood Cliffs.

Fachruddin dan Ali. (2009). Pengembangan Profesionalitas Guru. Jakarta: Gaung Persada.

M. Asrori. (tt). Collaborative Teamwork Learning: Suatu Model Pembelajaran untuk Mengembangkan Kemampuan Mahasiswa Bekerja secara Kolaboratif dalam Tim.

Mulyasa. (2005). Menjadi Guru Profesional Menciptakan Pembelajaran Kreatif dan Menyenangkan. Bandung: Rosdakarya.

Nurhadi. (2002). Pendekatan Kontekstual. Malang. Penerbit Universitas Negeri Malang.

Peraturan Pemerintah Nomor 19 Tahun 2005, Tentang Standar Nasional Pendidikan.

Purwanto, Ngalim. (2004). Administrasi dan Supervisi Pendidikan, Bandung: Remaja Rosdakarya.

Slavin, R. (1986). Educational Psychology Theory and Practice. Massachusects: Needham Heights.

Syaifuddin, M. dan Fatimah, S.(2007). Manajemen Berbasis Sekolah. Jakarta: Dirjen Dikti Depdiknas. 